\title{
soses
}

\section{THE DIRECT AND INDIRECT EFFECT OF EXCHANGE TO BUILD CUSTOMER LOYALTY IN SOCIAL NETWORK SITES}

\author{
DudiAnandya
}

t.

Surabaya Univesity

\section{INTRODUCTION}

The internet was found after World War 2, around 1950 (www.livinginternet.com), and since then it use has grown rapidly. The booming of intemet is supported by the development in information technology such as computer, broadband technology. Basically internet design to connect two or more computers in the distance. During 1950 the size of computer. was relatively big and very expensive, so only institution could buy a computer. With the development in computer technology, it becomes smaller and affordable. In 1980 has been known as the era of personal computer, where computer become personal and available for almost everybody. Today, computer becomes part of our life and carries around everyday.

Since computer becomes individualized, internet today is not only connecting all computers in the world, but also connects people who use those computers. At those times, there were networks between computer user, and known as social networks. These social networks are provided by the social network services such as Friendster and Facebook. Members in this two social network exchange information among them and share experience together. 